Kalsbeek, F. \& Taylor, P. N. 1983: Anatectic origin of mid-Proterozoic granite dyke in the Isukasia area, West Greenland. $\mathrm{Pb}-\mathrm{Pb}$ and $\mathrm{Rb}-\mathrm{Sr}$ isotope evidence. Rapp. Grønlands geol. Unders. 115, 38-42.

Kalsbeek, F., Bridgwater, D. \& Boak, J. 1980: Evidence of mid-Proterozoic granite formation in the Isua area. Rapp. Grønlands geol. Unders. 100, 73-75.

Nutman, A. P. 1982: Further work on the early Archaean rocks of the Isukasia area, southern West Greenland. Rapp. Grønlands geol. Unders. 110, 49-54.

Taylor, P. N., Moorbath, S., Goodwin, R. \& Petrykowski, A. C. 1980: Crustal contamination as an indicator of the extent of early Archaean continental crust: $\mathrm{Pb}$ isotope evidence from the late Archaean gneisses of West Greenland. Geochim. cosmochim. Acta 44, 1437-1454.

Watterson, J. 1978: Proterozoic intra-plate deformation in the light of S. E. Asian neotectonics. Nature, Lond. 273, 636-640.

Department of Geology, The University, Exeter EX4 4QE, U.K.

\title{
Textures of Archaean granites, Ivisârtoq region, southern West Greenland
}

\author{
Steven Robertson
}

Granite textures are widely believed to reflect the effect of extensive subsolidus (i.e. postmagmatic) recrystallisation. Detailed thin section observations of Archaean granites from the Ivisârtoq map sheet area, however, have revealed that subsolidus recrystallisation may by very limited. These observations apply to Qôrqut Granite Complex, 2610 Ma granites (Robertson, 1983) and Nûk granites from north-east Ivisârtoq. They all contain modal quartz, plagioclase and microcline in approximately equal proportions, with variable amounts of biotite ranging up to a maximum of $12 \%$ of the total. Accessory mineral phases include zircon, apatite, allanite, sphene, ilmenite, magnetite and occasionally pyrite. Textural relations suggest that the accessory phases crystallised at an early stage in the evolution of the granites and all appear to predate biotite, the earliest of the major minerals.

If any meaningful magmatic relationships are to be observed between the felsic minerals, then post-magmatic recrystallisation must be limited to grain boundaries. This is supported by the following observations of plagioclase-microcline grain boundaries. Plagioclase, where in contact with microcline, generally has a marginal zone of different optical orientation and/ or composition. This zone may, or may not be myrmekitic. Locally, the two types of zone occur at the same grain boundary, in which case the non-myrmekitic zone always rims the myrmekitic zone. The most common occurrence of the myrmekitic zones is as convex lobes penetrating into microcline with the microcline appearing to be a late crystallising phase. Myrmekite at planar plagioclase-microcline boundaries usually occurs in much thinner zones than those of the lobate myrmekite. Locally up to three distinct myrmekitic zones are developed on the same grain boundary (fig. 27). The dimensions of the quartz vermicules 

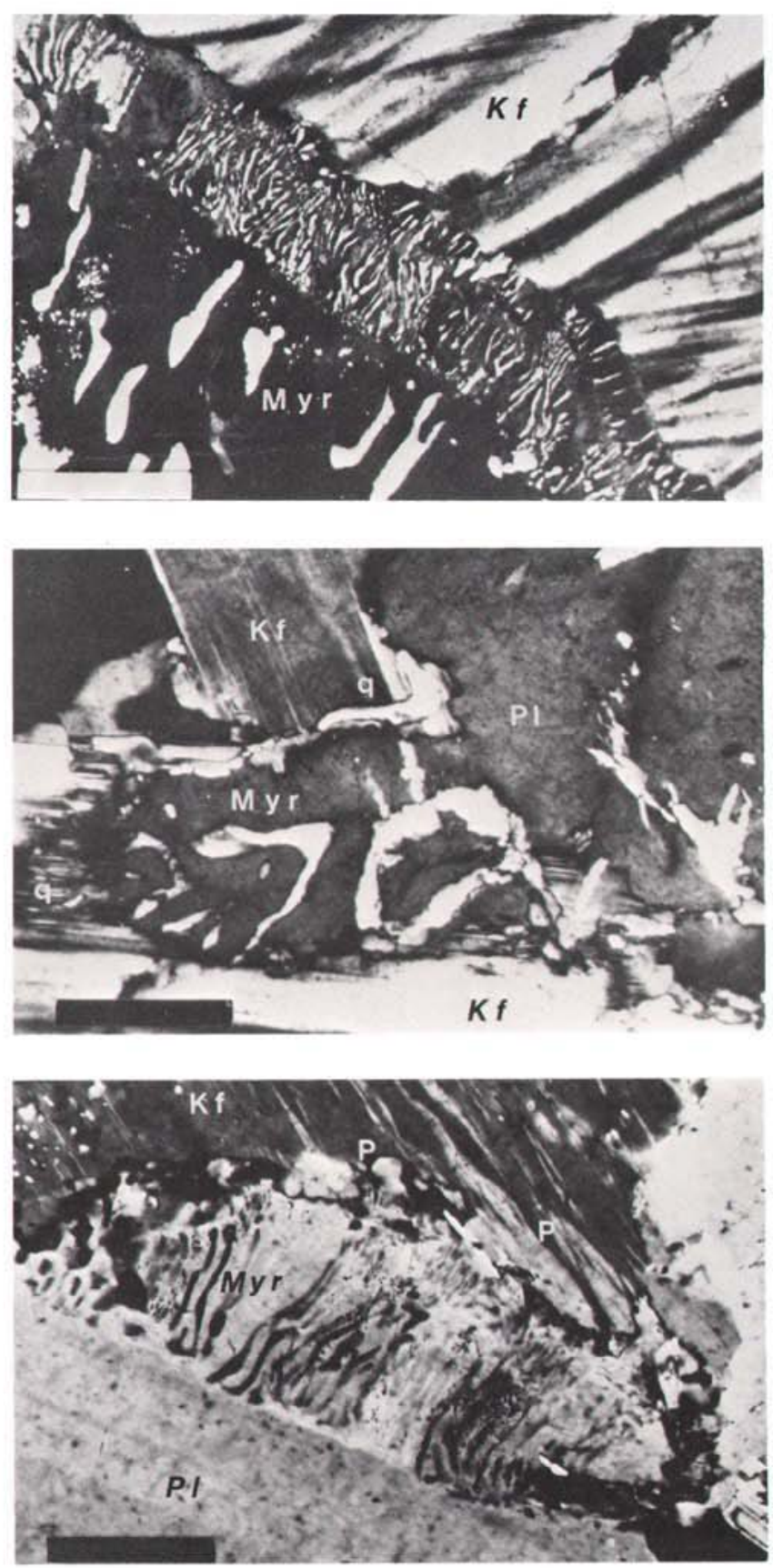

Fig. 27. Three myrmekitic zones developed at a plagioclase-microcline grain boundary. Plagioclase is in extiniction.

In all figures, $\mathrm{Pl}=$ plagioclase, $\mathrm{Kf}=$ microcline, $\mathrm{Myr}=$ myrmekite, $\mathrm{P}=$ perthite and $\mathrm{q}=$ myrmekitic quartz vermicules occurring in microcline. Scale bar $=0.2$ $\mathrm{mm}$.

Fig. 28. Myrmekite partly replaced by microcline as shown by quartz vermicules (white) occurring in microcline and cutting the plagioclase-microcline grain boundary. Abbreviations as in fig. 27.

Fig. 29. Lens of myrmekite developed on a planar plagioclase boundary. The boundary between the myrmekite and the microcline is sutured. A non-myrmekitic marginal zone is starting to develop as a result of migration of perthite. Recrystallised perthite is also indicated. Abbreviations as in fig. 27. 
decrease in successive zones towards the grain boundary. The ratio of quartz to plagioclase, however, does not change, i. e. the quartz vermicules are smaller but more abundant.

In many cases, partial replacement of the myrmekitic plagioclase by microcline has occurred, as shown by quartz vermicules occurring in microcline (or cutting a myrmekitemicrocline boundary) adjacent to a strongly sutured myrmekitic plagioclase-microcline boundary (fig. 28). Locally, the replaced zone is marked by small plagioclase inclusions at the edge of an optically distinct marginal zone in microcline. The location of the replaced plagioclase component is not known. If it is assumed that this marginal zone in the microcline is the result of late microcline growth by replacement of plagioclase, then in all cases less than $0.1 \mathrm{~mm}$ of plagioclase at the grain boundary has been replaced. In the granites from the Ivisârtoq region it is this that produces the sutured grain boundaries and apparent subsolidus recrystallisation.

Myrmekite has also been observed in long thin aggregates of plagioclase crystals occurring at microcline-microcline boundaries. This is less common than the two types described above.

The non-myrmekitic marginal zones of plagioclase generally occur at planar microclineplagioclase boundaries. In several cases these rims can be seen to be the product of recrystallisation and migration to grain boundaries of perthite lamellae. Similar plagioclase is produced by perthite migration to microcline-microcline boundaries and occasionally as trails across microclines. The non-myrmekitic zones are sometimes partly replaced by microcline.

Assuming that the Ivisârtoq region granites crystallised at pressures of between 2 and 5 $\mathrm{kb}$, then the alkali feldspar solvus will occur at a maximum of approximately $80^{\circ} \mathrm{C}$ below the granite solidus and therefore perthite represents an early subsolidus texture. In several cases, non-myrmekitic marginal plagioclase zones can be seen rimming myrmekitic plagioclase that has already been partly replaced by microcline (fig. 29). This is good evidence for the magmatic development of myrmekite. The consequences are obviously important. It suggests that all plagioclase on which myrmekite is developed is magmatic and that lobate myrmekite grew in the form of domes, overgrowing the plagioclase boundary, into fluid/melt i.e. the related microcline crystallised after the myrmekite. Also myrmekitic boundaries retained fluid/melt until a late stage in the evolution of the granites. Therefore, it is reasonable to assume that most mineral relationships, except for those at immediate grain boundaries, are magmatic.

Most published theories on myrmekite formation have involved subsolidus reaction/ recrystallisation of plagioclase and alkali feldspar (see Phillips, 1974, for a summary of previous models). Hibbard (1979), however, proposed that myrmekite crystallised directly from a magma. He suggested that myrmekite forms soon after a crystallising melt of appropriate composition becomes water-saturated. At this stage, the quartz and plagioclase phases remaining in the melt would separate from a potassium-rich phase. This would follow the aqueous fluid in a way similar to that proposed by Jahns \& Burnham (1969) to account for pegmatite-aplite genesis. Quenching of the quartz-plagioclase would produce the myrmekite, and changes in the crystallisation environment could produce several discrete zones of myrmekite while the potassium-rich aqueous fluid would crystallise as late alkali feldspar, possibly replacing marginal zones of plagioclase as observed in the Ivisârtoq region granites. Hibbard (1979) attributes myrmekite between alkali feldspar grains to the same process, with late crystallising melt located at grain boundaries. 
The textural observations in the granites of the Ivisârtoq region support the textural interpretations made by Hibbard (1979).

There are, as is to be expected, several problems. First, myrmekite in the deformed Nûk granites shows no evidence of deformation. However, the same problem would apply to a subsolidus model unless the myrmekite is envisaged as having developed several hundred million years after intrusion of the granites. Secondly, the question as to why extensive subsolidus recrystallisation has not taken place still exists. If it is assumed that the granites cooled slowly in the presence of fluids, metamorphic re-equilibration would be expected. Fluids can be seen to have been replacing narrow grain-boundary zones even after the development of perthite. However, only very limited areas were affected.

\title{
References
}

Hibbard, M. J. 1979: Myrmekite as a marker between preaqueous and postaqueous phase saturation in granitic systems. Bull. geol. Soc. Am. 90, 1047-1062.

Jahns, R. H. \& Burnham, C. W. 1969: Experimental studies of pegmatite genesis: I. A model for the derivation and crystallisation of granite pegmatites. Econ. Geol. 64, 843-864.

Phillips, E. R. 1974: Myrmekite - one hundred years later. Lithos 7, 181-194.

Robertson, S. 1983: Provisional results of isotope investigations into quartzo-feldspathic rocks from Kangiussap nunâ, Ivisârtoq sheet, southern West Greenland. Rapp. Grønlands geol. Unders. 115, $56-59$.

Department of Geology,

The University,

Exeter EX4 $4 Q E$,

U.K.

\section{A textural study of Archaean peridotites; Ujaragssuit nunât, Ivisârtoq region, southern West Greenland}

\author{
Martin A. Crewe
}

Recent mapping of Ujaragssuit nunât by Chadwick \& Crewe (1982) and Chadwick et al. (1983), following reconnaissance work by Allaart et al. (1977), has demonstrated the widespread occurrence of supracrustal lithologies. Ujaragssuit nunât is situated immediately to the north-west of Ivisârtoq, which has been described in some detail by Friend \& Hall (1977) and Hall (1980, 1981). Friend \& Hall (1977) noted that the Akilia association ultramafic rocks can be divided into two groups. The first group comprises those rocks rich 